\title{
Selection Responses for Clinical Mastitis and Protein Yield in Two Norwegian Dairy Cattle Selection Experiments
}

\author{
B. Heringstad, ${ }^{\star}$ G. Klemetsdal, ${ }^{*}$ and T. Steine† \\ *Department of Animal Science, Agricultural University of Norway, \\ †GENO Breeding and A. I. Association, \\ P. O. Box 5025, N-1432 Ås, Norway
}

\section{ABSTRACT}

Inferences from two dairy cattle selection experiments, in which sires were selected from external sources, were drawn by using an animal model to analyze data from the entire population. The first selection experiment was carried out in the period from 1978 to 1989 and included groups selected for high milk production (HMP) and low milk production (LMP). Each year, the highest ranking proven sires for milk production, from the most recent group of Norwegian Dairy Cattle (NRF) test bulls, were selected and mated to the cows in the HMP group. A group of sires with low milk production indices from progeny testing in 1978 and 1979 were used as sires in the LMP group during the entire experiment. The second selection experiment, which started in 1989, included one high protein yield (HPY) group and one low clinical mastitis (LCM) group. The highest ranking proven NRF sires for protein yield and mastitis resistance were selected each year from the most recent group of progeny tested bulls and used as sires in the HPY and LCM groups, respectively. Genetic trends for protein yield were positive (as expected) for HMP and HPY cows, and negative for LMP and LCM cows. Estimates of annual genetic trends for clinical mastitis were $+0.23,-0.02,+0.04$, and $-0.91 \%$ per year for HMP, LMP, HPY, and LCM cows, respectively. The difference in genetic trend of clinical mastitis between HMP and HPY groups, both selected for increased milk production, reflects the gradual change in the NRF breeding objective towards more weight on health relative to milk over the last $20 \mathrm{yr}$. After four cow generations, the genetic difference in mastitis between HMP and LMP group cows was $3.1 \%$ clinical mastitis, a correlated response to selection for increased milk production. The genetic difference between LCM and HPY cows of $8.6 \%$ clinical mastitis

Received October 4, 2002.

Accepted April 22, 2003.

Corresponding author: B. Heringstad; e-mail: bjorg.heringstad@ ihf.nlh.no. after three cow generations is mainly a result of direct selection against clinical mastitis in the LCM group. In the NRF population, an approximately flat genetic trend for clinical mastitis was found for cows born from 1976 to 1990 , whereas cows born after 1990 showed a genetic improvement equivalent to a reduction of $0.19 \%$ clinical mastitis per year. The results show that it is possible to obtain considerable selection response for clinical mastitis, and that selection for increased milk production will result in an unfavorable correlated increase in mastitis incidence, if mastitis is ignored in the breeding program.

(Key words: clinical mastitis, protein yield, selection experiment, selection response)

Abbreviation key: $\mathbf{C M}=$ clinical mastitis, $\mathbf{H M P}=$ high milk production group, HPY = high protein yield group, $\mathbf{L C M}=$ low clinical mastitis group, LMP = low milk production group, NRF = Norwegian Dairy Cattle.

\section{INTRODUCTION}

Two dairy cattle selection experiments have been carried out in collaboration between GENO Breeding and A. I. Association and the Department of Animal Science, Agricultural University of Norway. In the first experiment, which was carried out from 1978 to 1989, selection was for groups with high (HMP) and low milk production (LMP), respectively. The second experiment began in 1989 and continues today. This experiment includes two groups, selected for high protein yield and low mastitis frequency, respectively. This latter experiment is unique as it is the first selection experiment in dairy cattle with direct selection against clinical mastitis.

In both experiments, sires were selected based on their progeny testing results in the Norwegian Dairy Cattle (NRF) population. For low milk production, a group of 21 sires was initially selected based on their progeny test results in 1978 and 1979; and these bulls were used exclusively during the entire experiment. Otherwise, for each selection group and year, the 2 to 7 highest ranking sires for the respective trait were 
selected from the most recent group of progeny tested bulls. No consideration was made with respect to EBV for other traits. This approach implies single-trait selection of sires, which were preselected for the NRF breeding objective. In NRF, 120 to 130 bulls are progeny tested each year with an average of 250 to 300 daughters per sire. Norwegian dairy cattle have been selected for a broad breeding objective, with steadily increasing emphasis on functional traits like health and fertility over time (Heringstad et al., 2001). The current breeding objective results in genetic improvement of both protein yield and mastitis resistance (Heringstad et al., 2001, 2003), despite the unfavorable genetic correlation between these traits. Heringstad et al. (2000) summarized the estimates of genetic correlation between clinical mastitis and milk production based on Nordic field data and found estimates ranging from 0.24 to 0.55 , with an average of 0.43 . Recent estimates of the genetic correlation between clinical mastitis and milk production range from 0.25 to 0.45 (Heringstad et al., 1999; Lund et al., 1999; Rupp and Boichard, 1999; Hansen et al., 2002).

Due to the unfavorable genetic correlation between mastitis and milk production, selection for increased milk production is expected to result in a genetic deterioration of mastitis if mastitis is ignored in the breeding program. This response has been confirmed in simulation studies (Strandberg and Shook, 1989; Colleau and le Bihan-Duval, 1995) but never demonstrated with real data, because populations that ignore mastitis in the breeding program generally do not record the trait.

The main objective of this paper was to estimate selection responses for clinical mastitis and protein yield in the two previously described selection experiments. Results from these selection experiments may provide estimation of both the correlated response in clinical mastitis resulting from single trait selection for increased milk production, as well as responses to direct selection against clinical mastitis.

\section{MATERIALS AND METHODS}

In both experiments, sires were selected externally from the population at large. To take this factor into account, all available data from the total NRF population from 1978 onward were analyzed with an animal model. The EBV for the cows in the experiments were extracted from these analyses and used for calculation of genetic trends in the selection groups. Results are presented for the two selection experiments and for the entire NRF population. This work represents the first analysis of the NRF population using an animal model.

\section{Selection Experiments}

Selection experiment I. The first selection experiment was carried out in the period from 1978 to 1989. Eight herds were included in the experiment (Table 1). Two selection groups were established based on NRF cows present in the herds when the experiment began. Cows were randomly assigned to either a HMP or a LMP group. Each year, the three to seven highest ranking proven sires for milk production were selected from the most recent group of progeny tested NRF sires and mated to the HMP cows (total 49 sires). Sires were used only $1 \mathrm{yr}$, so very close inbreeding (e.g., father-daughter mating) was therefore avoided. For the LMP group, 21 sires with milk production indices approximately equal to 90 from progeny testing in 1978 and 1979 were selected and used as sires during the entire experimental period. Sires in LMP were used in a rotational system (six to nine sires were used per year) to avoid inbreeding. The milk production index was a relative index with mean 100 and SD 6 . Sires were selected based on EBV for 305-d lactation milk production in first lactation, which had been calculated somewhat differently over time (Ødegård, 2000). Until 1978 the selected trait was kg FCM (kg milk [0.4 $+0.15 \times$ fat\%]). In the period 1979 to 1985 , the selection criteria was kg milk, fat percentage, and protein percentage, with twice as much weight on protein percentage as on fat percentage ( $\mathrm{kg}$ milk $[0.22+$ $0.075 \times$ fat\% $+0.15 \times$ protein\%]). From 1986 to 1989 , the criteria was $\mathrm{kg}$ milk with five times as much weight on protein percentage as on fat percentage $(\mathrm{kg}$ milk $[0.20+0.04 \times$ fat $\%+0.20 \times$ protein $\%])$. In 1989 , the selection criterion was changed to $305-d$ protein yield (kg protein). Directional selection of cows was not practiced in either group. At the end of this experiment, in 1989, most calves and heifers in the LMP group were culled, while animals from HMP were kept in the herds and produced first-lactation records. Therefore, five generations of HMP cows and four generations of LMP cows were included in the analyses.

Cow generation. For these analyses, all cows present in the herds when the selection experiment started, that were mated with one of the defined sires and produced a daughter that made a first lactation record of mastitis and/or protein yield were defined as cow-generation 0 . The daughters of these cows were defined as cow-generation 1 , and so on. Therefore, cows born in the same year may belong to different cow-generations. Each year, new sires were selected and mated to cows of all generations, so cows in the same cow-generation have sires selected in different years in the HMP group. 
Table 1. Number of cows with EBV for clinical mastitis per selection group (HMP = high milk production, LMP = low milk production), cow generation, and herd in selection experiment I.

\begin{tabular}{|c|c|c|c|c|c|c|c|c|c|c|}
\hline \multirow[b]{2}{*}{ Herd } & \multicolumn{2}{|c|}{ Group } & \multicolumn{7}{|c|}{ Cow generation ${ }^{1}$} & \multirow{2}{*}{$\begin{array}{l}\text { Total no } \\
\text { cows }\end{array}$} \\
\hline & HMP & LMP & 0 & 1 & 2 & 3 & 4 & 5 & 6 & \\
\hline Kalnes & 317 & 313 & 145 & 178 & 162 & 113 & 30 & 2 & 0 & 630 \\
\hline Hvam & 112 & 99 & 51 & 63 & 50 & 30 & 15 & 2 & 0 & 211 \\
\hline Jønsberg & 128 & 135 & 56 & 81 & 64 & 46 & 13 & 3 & 0 & 263 \\
\hline Melsom & 162 & 117 & 66 & 87 & 69 & 45 & 12 & 0 & 0 & 279 \\
\hline Åna & 392 & 244 & 130 & 185 & 149 & 113 & 49 & 10 & 0 & 636 \\
\hline Øksnevad & 126 & 83 & 53 & 73 & 49 & 26 & 6 & 1 & 1 & 209 \\
\hline Gjermundnes & 89 & 48 & 28 & 37 & 34 & 26 & 11 & 1 & 0 & 137 \\
\hline Mære & 228 & 129 & 71 & 95 & 88 & 68 & 30 & 5 & 0 & 357 \\
\hline Total number of cows & 1554 & 1168 & 600 & 799 & 665 & 467 & 166 & 24 & 1 & 2722 \\
\hline \multirow[t]{2}{*}{ Selection group } & HMP & & 311 & 411 & 370 & 311 & 130 & 20 & 1 & \\
\hline & LMP & & 289 & 388 & 295 & 156 & 36 & 4 & 0 & \\
\hline
\end{tabular}

\footnotetext{
${ }^{1}$ Cow generation $=$ All cows present in the herd when the selection experiment started that were mated with one of the defined sires and produced a daughter that made a first-lactation record of mastitis and/or protein yield were defined as cow generation 0, all their daughters were defined as cow generation 1 and so on.
}

Selection experiment II. In 1989 another selection experiment was initiated, based mainly on the HMP cows from the first experiment. Eight herds were included: six of the herds from the first experiment and two new school herds (Table 2). Cows were randomly assigned to either a high protein yield (HPY) or a low clinical mastitis (LCM) group. Each year the 3 to 4 highest ranking proven sires for $305-d$ protein yield (one selection criterion) were selected from the most recent group of NRF test-bulls and mated to HPY cows. Correspondingly, each year the two to four best proven sires for mastitis resistance (the other selection criterion) were selected and mated to LCM cows. This mating design, corresponding to that of HMP in experiment I, efficiently avoids close inbreeding. As in experiment I, there was no directional selection of cows in either group. Approximately $70 \%$ of the cows in generation 0 were HMP cows from experiment I, $8 \%$ were LMP cows, and $22 \%$ were other NRF cows (mainly cows in the two new herds). In cow generation $1,75 \%$ of LCM cows and $64 \%$ of the HPY cows had mothers from HMP. Three generations of cows had completed first lactation at the time of these analyses. This experiment is ongoing.

\section{Data}

NRF population. Data were extracted from a research database containing all phenotypic information from the Norwegian Dairy Herd Recording System since 1978. The mastitis data file included information regarding clinical mastitis (CM) during first lactation for all cows with date of first calving between September 1st 1978 and September 1st 1998. A record

Table 2. Number of cows with EBV for clinical mastitis per selection group (HPY = high protein yield, LCM = low clinical mastitis), cow generation, and herd in selection experiment II.

\begin{tabular}{|c|c|c|c|c|c|c|c|c|}
\hline \multirow[b]{2}{*}{ Herd } & \multicolumn{2}{|c|}{ Group } & \multicolumn{5}{|c|}{ Cow generation ${ }^{1}$} & \multirow{2}{*}{$\begin{array}{l}\text { Total } \\
\text { number of } \\
\text { cows }\end{array}$} \\
\hline & HPY & LCM & 0 & 1 & 2 & 3 & 4 & \\
\hline Kalnes & 200 & 173 & 122 & 151 & 84 & 16 & 0 & 373 \\
\hline Jønsberg & 51 & 58 & 35 & 48 & 21 & 5 & 0 & 109 \\
\hline Valle & 119 & 68 & 65 & 73 & 44 & 5 & 0 & 187 \\
\hline Buskerud & 68 & 55 & 39 & 50 & 31 & 3 & 0 & 123 \\
\hline Åna & 185 & 201 & 102 & 153 & 109 & 22 & 0 & 386 \\
\hline Øksnevad & 81 & 58 & 46 & 55 & 31 & 7 & 0 & 139 \\
\hline Gjermundnes & 37 & 43 & 19 & 31 & 24 & 5 & 1 & 80 \\
\hline Mære & 107 & 86 & 58 & 76 & 49 & 10 & 0 & 193 \\
\hline Total number of cows & 848 & 742 & 486 & 637 & 393 & 73 & 1 & 1590 \\
\hline \multirow[t]{2}{*}{ Selection group } & HPY & & 260 & 345 & 208 & 35 & 0 & \\
\hline & LCM & & 226 & 292 & 185 & 38 & 1 & \\
\hline
\end{tabular}

${ }^{1}$ Cow generation $=$ All cows present in the herd when the selection experiment started that were mated with one of the defined sires and produced a daughter that made a first-lactation record of mastitis and/or protein yield were defined as cow-generation 0 , all their daughters were defined as cow generation 1 and so on. 
Table 3. Summary statistics of the datasets used for prediction of breeding values for clinical mastitis and protein yield.

\begin{tabular}{|c|c|c|}
\hline & Clinical mastitis & Protein yield \\
\hline Cows with data, no. & $2,033,941$ & $1,576,579$ \\
\hline Herds, no. & 29,055 & 29,158 \\
\hline Herd $\times$ year classes, no. & 413,210 & 412,972 \\
\hline Mastitis frequency ${ }^{1}, \%$ & 15.0 & \\
\hline Mean 305-d protein yield ${ }^{2}, \mathrm{~kg}$ & & 170.1 \\
\hline SD 305-d protein yield ${ }^{2}, \mathrm{~kg}$ & & 34.9 \\
\hline Animals in the pedigree file, no. & $2,316,164$ & $1,897,747$ \\
\hline Base animals in the pedigree file, no. & 86,417 & 70,984 \\
\hline
\end{tabular}

${ }^{1}$ Mastitis frequency $=$ Percentage of cows with at least one record of veterinary treated clinical mastitis in the period from $15 \mathrm{~d}$ before to $120 \mathrm{~d}$ after first calving.

${ }^{2}$ Only cows with complete $305-d$ lactation were included.

was included if age of first calving was between 450 and $1200 \mathrm{~d}$ and the lactation began with a normal calving. To ensure participation in the health recording system, only cows from herds with at least one health recording during the year the cow calved were included. Mastitis was defined as a binary trait based on whether or not the cow had at least one case of veterinary treated $\mathrm{CM}$ in the period from $15 \mathrm{~d}$ before to $120 \mathrm{~d}$ after first calving. This definition is the same as currently used for genetic evaluation of the trait in $\mathrm{NRF}$. The resulting file contained CM information for $2,033,941$ cows and the average CM frequency was $15 \%$ (Table 3). Data on 305-d protein yield in first lactation were extracted using the same criteria for calving period, age of first calving, and start of lactation as for CM. Only cows with complete 305-d lactation records were considered. Mean and SD of 305-d protein yield was 170.1 and 34.9 , respectively (Table 3 ). The resulting file contained information on 305-d protein yield for $1,576,579$ cows (Table 3 ). The structure of the data sets is shown in Table 3.

Selection experiment I. A total of 2496 cows from experiment I had first-lactation CM records, including 1427 HMP cows and 1069 LMP cows (Table 4). The average mastitis frequencies were $18.3 \%$ for HMP cows and $12.8 \%$ for LMP cows (Table 4). A total of 1815 cows, 1098 from the HMP group, and 717 from the LMP group, completed 305-d of first lactation (Table 4). The average 305-d protein yields were $185.1 \mathrm{~kg}$ and $165.1 \mathrm{~kg}$ for HMP and LMP cows, respectively (Table 4). A total of 2722 cows had EBV for CM, and the numbers per herd, selection group and cow-generation are given in Table 1.

Selection experiment II. A total of 1566 cows in experiment II had first lactation CM records, of which 831 were HPY cows and 735 were LCM cows. Mean frequencies of CM were 15.2 and $15.0 \%$ for HPY and LCM, respectively (Table 4). A total of 1117 cows, 610 from the HPY group and 507 from the LCM group, completed 305-d of first lactation, with a mean 305-d protein yield of $185.9 \mathrm{~kg}$ for HPY cows and $178.5 \mathrm{~kg}$ for LCM cows (Table 4). A total of 1590 cows had EBV for CM, distributed over selection groups, cowgenerations, and herds as shown in Table 2.

\section{Pedigree File}

The initial pedigree file for the NRF population included 3.7 million records. From this file, separate

Table 4. Summary statistics for high milk production (HMP) and low milk production (LMP) group cows from selection experiment I, and high protein yield (HPY) and low clinical mastitis (LCM) group cows from selection experiment II.

\begin{tabular}{llccc}
\hline & \multicolumn{3}{c}{ Selection group } \\
\cline { 2 - 5 } & HMP & LMP & HPY & LCM \\
\hline Cows with first-lactation clinical mastitis observation & 1427 & 1069 & 831 & 735 \\
Cows with EBV for clinical mastitis & 1554 & 1168 & 848 & 742 \\
Mastitis frequency, $\%$ (18.3 & 12.8 & 15.2 & 15.0 \\
Cows with first lactation 305-d protein yield observation & 1098 & 717 & 610 & 507 \\
Cows with EBV for 305-d protein yield & 1306 & 871 & 671 & 560 \\
Mean 305-d protein yield, kg & 185.1 & 165.1 & 185.9 & 178.5 \\
SD 305-d protein yield, kg & 30.9 & 30.4 & 34.8 & 34.5 \\
Sires, no. & 49 & 21 & 24 & 17 \\
\hline
\end{tabular}

${ }^{1}$ Mastitis frequency = Percentage of cows with at least one record of veterinary treated clinical mastitis in the period from $15 \mathrm{~d}$ before to $120 \mathrm{~d}$ after first calving.

${ }^{2}$ Only cows with complete 305 -d lactation were included. 

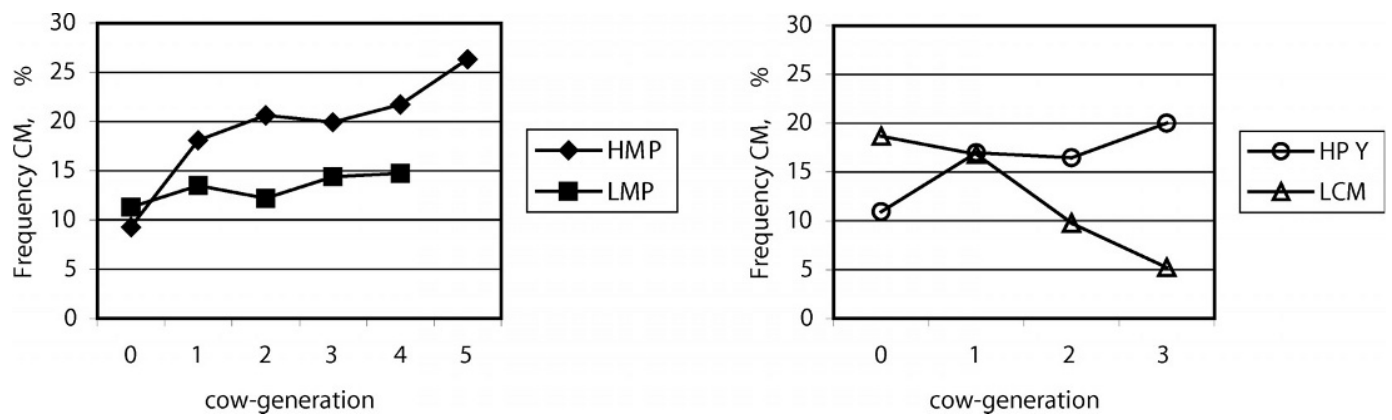

Figure 1. Mean mastitis frequency, as percentage of cows with at least one case of clinical mastitis (CM) in the period from $15 \mathrm{~d}$ before to $120 \mathrm{~d}$ after first calving, per cow generation in two selection experiments, with high milk production (HMP) and low milk production (LMP) groups in experiment I, and high protein yield (HPY) and low clinical mastitis (LCM) groups in experiment II.

pedigree files for the cows in the $\mathrm{CM}$ and protein yield datasets were derived by tracing the pedigrees for cows with data back as far as possible. The resulting pedigree files had 2,316,164 (CM) and 1,897,747 (protein yield) observations, respectively (Table 3 ). A total of $3.7 \%$ of the animals in the pedigree-files were base animals.

\section{Model}

Breeding values for $\mathrm{CM}$ were calculated using the following linear model:

$$
\mathrm{Y}_{\mathrm{ijkl}}=\mathrm{A}_{\mathrm{i}}+\mathrm{M}_{\mathrm{j}}+\mathrm{HY}_{\mathrm{k}}+\mathrm{a}_{\mathrm{l}}+\mathrm{e}_{\mathrm{ijkl}}
$$

where

$$
\begin{aligned}
\mathrm{Y}_{\mathrm{ijkl}}= & \text { observation of CM }(0=\text { healthy, } 1=\text { dis- } \\
& \text { eased }) \text { for cow } l \text {, calving at age } i, \text { in month } \\
& j, \text { and herd } \times \text { year class } k ; \\
\mathrm{A}_{\mathrm{i}}= & \text { fixed effect of age at calving } i \text { in } 15 \\
& \text { classes, where }<20 \text { mo is the first class, } \\
& >32 \text { mo the last class, and the other } \\
& \text { classes are in single months; } \\
\mathrm{M}_{\mathrm{j}}= & \text { fixed effect of month of calving } j \text { in } 12 \\
& \text { classes; } \\
\mathrm{HY}_{\mathrm{k}}= & \text { fixed effect of herd-year class } k ; \\
\mathrm{a}_{\mathrm{l}}= & \text { random effect of animal } l \text {; and } \\
\mathrm{e}_{\mathrm{ijkl}}= & \text { random error term. }
\end{aligned}
$$

Protein yield was analyzed using the model:

$$
\mathrm{Y}_{\mathrm{ijklm}}=\mathrm{A}_{\mathrm{i}}+\mathrm{M}_{\mathrm{j}}+\mathrm{DO}_{\mathrm{k}}+\mathrm{HY}_{\mathrm{l}}+\mathrm{a}_{\mathrm{m}}+\mathrm{e}_{\mathrm{ijklm}}
$$

where

$$
\begin{aligned}
\mathrm{Y}_{\mathrm{ijklm}}= & \text { observation of 305-d protein yield (kg pro- } \\
& \text { tein) for cow } m \text {, calving at age } i \text {, in month }
\end{aligned}
$$

$$
\begin{aligned}
& j \text {, days open class } k \text { and herd } \times \text { year class } \\
l & \text {; } \\
\mathrm{DO}_{\mathrm{k}}= & \text { fixed effect of days open } k \text { in } 14 \text { classes, } \\
& \text { where }<30 \mathrm{~d} \text { is the first class, }>149 \mathrm{~d} \text { is } \\
& \text { the last class, and the other classes are } \\
& \text { in } 10 \mathrm{~d} \text { intervals; and }
\end{aligned}
$$

other effects were as defined previously for CM.

The models included the same fixed effects as the linear sire models used by Heringstad et al. (1999; 2001). Univariate analyses were chosen because a previous study (Heringstad et al., 2001) showed that estimates of genetic trends in this population were the same from univariate analyses and bivariate analysis of $\mathrm{CM}$ and protein yield.

Variance components for $\mathrm{CM}$ and 305-d protein yield were estimated with VCE4 (Neumaier and Groeneveld, 1998) using linear sire models with the same fixed effects as described above and data restricted to daughters of sires progeny tested in the years from 1978 to 1998 . The resulting sire $\left(\sigma_{\mathrm{s}}^{2}\right)$ and residual $\left(\sigma_{\mathrm{e}-\mathrm{s}}^{2}\right)$ variances were used to calculate variance components relevant for the animal model as follows:

$$
\begin{aligned}
& \sigma_{\mathrm{a}}^{2}=4 \sigma_{\mathrm{s}}^{2} \text { and } \\
& \sigma_{\mathrm{e}}^{2}=\sigma_{\mathrm{e}-\mathrm{s}}^{2}-3 \sigma_{\mathrm{s}}^{2} .
\end{aligned}
$$

Additive relationship matrices were included in the analyses, and breeding values were estimated using the program PEST (Groeneveld and Kovac, 1990).

Genetic trends were estimated by linear regression of EBV on cow generation and cows birth-year, and $t$ tests were used to test whether the regression coefficients were different from zero and to assess whether mean EBV were significantly different between selection groups for each cow generation. 
Table 5. Mean EBV for clinical mastitis $\left(\mathrm{EBV}_{\mathrm{CM}}\right)$ and 305-d protein yield $\left(\mathrm{EBV}_{\mathrm{PY}}\right)$ of sires mated to high milk production (HMP) or low milk production (LMP) group cows in selection experiment I, per year and selection group.

\begin{tabular}{|c|c|c|c|c|c|c|}
\hline \multirow[b]{2}{*}{ Year } & \multicolumn{3}{|c|}{ HMP } & \multicolumn{3}{|c|}{ LMP } \\
\hline & No. sires & Mean $\mathrm{EBV}_{\mathrm{CM}}$ & Mean $\mathrm{EBV}_{\mathrm{PY}}$ & No. sires & Mean $\mathrm{EBV}_{\mathrm{CM}}$ & Mean $\mathrm{EBV}_{\mathrm{PY}}$ \\
\hline 1978 & 7 & 0.0268 & 11.53 & 9 & -0.0147 & -8.66 \\
\hline 1979 & 4 & 0.0468 & 16.17 & 12 & -0.0009 & -11.48 \\
\hline 1980 & 6 & -0.0178 & 7.17 & & & \\
\hline 1981 & 7 & 0.0108 & 4.34 & & & \\
\hline 1982 & 3 & 0.0816 & 7.78 & & & \\
\hline 1983 & 3 & 0.0536 & 11.18 & & & \\
\hline 1984 & 3 & 0.0026 & 10.89 & & & \\
\hline 1985 & 3 & 0.0285 & 15.51 & & & \\
\hline 1986 & 3 & 0.0472 & 15.66 & & & \\
\hline 1987 & 3 & -0.0142 & 13.25 & & & \\
\hline 1988 & 4 & 0.0532 & 19.32 & & & \\
\hline 1989 & 3 & 0.0415 & 21.30 & & & \\
\hline
\end{tabular}

\section{RESULTS AND DISCUSSION}

Figure 1 shows mean mastitis frequency per cow generation in the two selection experiments. Cows in the LMP group show a relatively flat phenotypic trend, whereas mastitis frequency in the HMP group increased with cow generation. In selection experiment II, mastitis frequency decreased in the LCM group and increased somewhat for the HPY group. Phenotypic mastitis frequency in cow generation 0 was higher in the LCM group than in the HPY group.

The variance components for animal $\left(\sigma_{\mathrm{a}}^{2}\right)$ and residual $\left(\sigma_{\mathrm{e}}^{2}\right)$ effects were 0.0038 and 0.1198 for $\mathrm{CM}$, and 100.8 and 427.2 for 305 -d protein yield, corresponding to heritabilities of 0.03 and 0.19 , respectively. The overall mean (SD) EBV for CM and 305-d protein yield in the total dataset were $0.002(0.029)$ and 3.07 (6.28), respectively. Annual mean EBV for CM and 305-d protein yield for sires used in the two experiments are given in Tables 5 and 6 .
Mean EBV for CM in the two selection experiments are given in Figure 2. The genetic trend for LMP cows was flat, while mean EBV for CM in the HMP group increased with cow generation. Mean EBV was significantly different $(P<0.0001)$ between the two selection groups from cow generation 1 onwards. The genetic difference in CM between HMP and LMP cows in experiment I, equivalent to $3.1 \% \mathrm{CM}$ after four cowgenerations, is most likely a correlated response in CM after selection for increased milk production in the HMP group. In selection experiment II, the genetic level of CM in cow generation 0 was the same for the two groups (Figure 2). The genetic trend of CM was approximately flat for HPY cows and strongly decreasing in the LCM group. Mean EBV was significantly different $(P<0.0001)$ in HPY and LCM from cow generation 1 onwards. Here, the genetic difference of $8.6 \%$ $\mathrm{CM}$ after three cow generations is mainly a result of direct selection against CM in the LCM group.

Linear regression analyses of EBV for $\mathrm{CM}$ on cow generation indicated a genetic increase of $0.78 \%$ and

Table 6. Mean EBV for clinical mastitis $\left(\mathrm{EBV}_{\mathrm{CM}}\right)$ and $305-\mathrm{d}$ protein yield $\left(\mathrm{EBV}_{\mathrm{PY}}\right)$ of sires mated to high protein yield (HPY) and low clinical mastitis (LCM) group cows, in selection experiment II, per year and selection group.

\begin{tabular}{llllllll}
\hline & \multicolumn{3}{c}{ HPY } & & \multicolumn{3}{c}{ LCM } \\
\cline { 2 - 3 } Year & No. of sires & Mean EBV $_{\mathrm{CM}}$ & Mean EBV $_{\text {PY }}$ & & No. of sires & Mean EBV $_{\mathrm{CM}}$ & Mean EBV $_{\text {PY }}$ \\
\hline 1989 & 3 & 0.0415 & 21.30 & 2 & -0.0772 & -2.82 \\
1990 & 3 & 0.0016 & 19.91 & 2 & -0.0773 & -0.02 \\
1991 & 4 & 0.0535 & 24.79 & 2 & -0.0622 & -8.66 \\
1992 & 3 & 0.0156 & 23.82 & 2 & -0.1071 & 8.27 \\
1993 & 3 & 0.0059 & 26.15 & 3 & -0.0575 & 3.76 \\
1994 & 4 & 0.0261 & 21.54 & 3 & -0.0928 & 2.78 \\
1995 & 4 & 0.0425 & 26.30 & 3 & -0.0596 & 5.79 \\
1996 & 3 & -0.0341 & 27.70 & 3 & -0.0626 & 1.32 \\
1997 & 4 & 0.0056 & 22.81 & 4 & -0.0678 & 1.79 \\
1998 & 3 & 0.0021 & 29.90 & 4 & -0.0748 & 9.39 \\
\hline
\end{tabular}



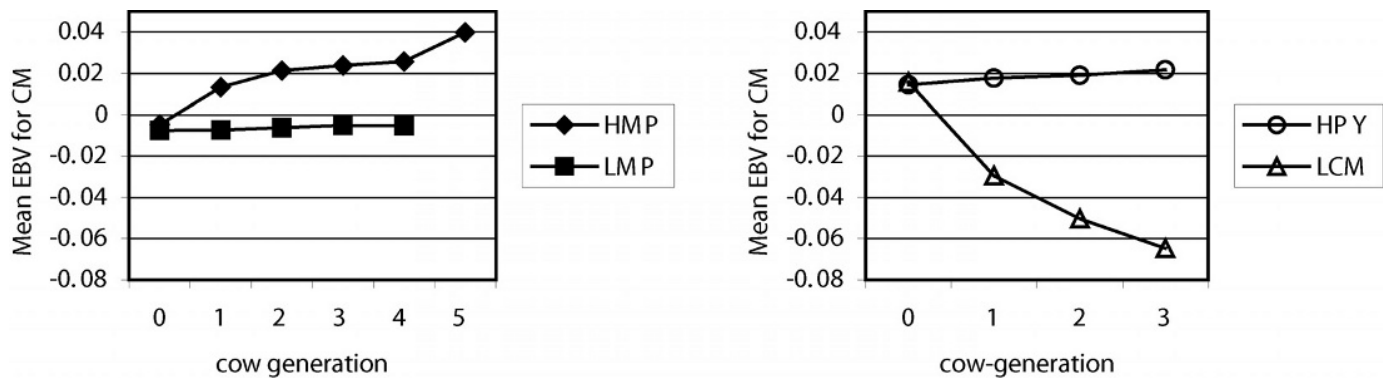

Figure 2. Mean EBV for clinical mastitis (CM) per cow generation for cows in two selection experiments, with high milk production (HMP) and low milk production (LMP) groups in experiment I, and high protein yield (HPY) and low mastitis frequency (LCM) groups in experiment II.

$0.24 \% \mathrm{CM}$ per cow generation for HMP and HPY cows, respectively (Table 7). A genetic improvement equivalent to a reduction of $3.03 \% \mathrm{CM}$ per cow generation was estimated for the LCM group, and an approximately flat genetic trend was found for the LMP group (Table 7). The regression coefficients for HMP and LCM were significantly different from zero $(P<$ 0.0001 ), whereas the levels of significance were 0.058 and 0.173 for HPY and LMP, respectively (Table 7).

Mean EBV for CM per birth-year in the NRF population and for selection groups in the two experiments are given in Figure 3. Genetic trend for CM in the NRF population was approximately flat for cows born before 1990 and slightly decreasing thereafter. The corresponding regression coefficients indicate a genetic change of $+0.04 \% \mathrm{CM}$ per year from 1976 to 1990 , and $-0.19 \% \mathrm{CM}$ per year from 1990 onwards (Table 7). This agreed closely with Heringstad et al. (2003) who found a similar result using linear and threshold sire models. However, the estimate of annual genetic change after 1990 was slightly lower from the animal model $(-0.19 \% \mathrm{CM})$ than the estimate of Heringstad

Table 7. Regression coefficients from linear regression analysis of EBV for clinical mastitis $\left(\mathrm{EBV}_{\mathrm{CM}}\right)$ and 305-d protein yield $\left(\mathrm{EBV}_{\mathrm{PY}}\right)$ on cow generation and birth-year of cow, respectively, for high milk production (HMP) and low milk production (LMP) group cows from selection experiment I, and high protein yield (HPY) and low clinical mastitis (LCM) group cows from selection experiment II, and for the entire Norwegian Dairy Cattle (NRF) population.

\begin{tabular}{|c|c|c|c|c|c|}
\hline $\begin{array}{l}\text { Dependent } \\
\text { variable }\end{array}$ & $\begin{array}{l}\text { Independent } \\
\text { variable }\end{array}$ & Group & $\begin{array}{l}\text { Generation/ } \\
\text { period }\end{array}$ & $\begin{array}{l}\text { Regression } \\
\text { coefficient }^{1}\end{array}$ & $P$-value ${ }^{2}$ \\
\hline \multirow[t]{11}{*}{$\mathrm{EBV}_{\mathrm{CM}}$} & \multirow[t]{4}{*}{ Cow generation ${ }^{3}$} & HMP & $0-5$ & 0.78 & $<0.0001$ \\
\hline & & LMP & $0-4$ & 0.08 & 0.173 \\
\hline & & HPY & $0-3$ & 0.24 & 0.058 \\
\hline & & LCM & $0-3$ & -3.03 & $<0.0001$ \\
\hline & \multirow[t]{7}{*}{ Birth-year cow } & HMP & 1976-1990 & 0.23 & $<0.0001$ \\
\hline & & LMP & $1976-1990$ & -0.02 & 0.307 \\
\hline & & HPY & $1987-1996$ & 0.04 & 0.317 \\
\hline & & LCM & 1987-1996 & -0.91 & $<0.0001$ \\
\hline & & $\mathrm{NRF}$ & $1976-1996$ & -0.01 & $<0.0001$ \\
\hline & & NRF & $1976-1990$ & 0.04 & $<0.0001$ \\
\hline & & $\mathrm{NRF}$ & $1990-1996$ & -0.19 & $<0.0001$ \\
\hline \multirow[t]{9}{*}{$\mathrm{EBV}_{\mathrm{PY}}$} & \multirow[t]{4}{*}{ Cow-generation ${ }^{3}$} & HMP & $0-5$ & 3.23 & $<0.0001$ \\
\hline & & LMP & $0-4$ & -2.83 & $<0.0001$ \\
\hline & & HPY & $0-3$ & 4.85 & $<0.0001$ \\
\hline & & LCM & $0-3$ & -1.97 & $<0.0001$ \\
\hline & \multirow{5}{*}{ Birth-year cow } & HMP & $1976-1990$ & 1.00 & $<0.0001$ \\
\hline & & LMP & $1976-1990$ & -0.87 & $<0.0001$ \\
\hline & & HPY & $1987-1996$ & 1.40 & $<0.0001$ \\
\hline & & LCM & 1987-1996 & -0.50 & 0.0003 \\
\hline & & NRF & $1976-1996$ & 0.47 & $<0.0001$ \\
\hline
\end{tabular}

\footnotetext{
${ }^{1}$ For CM: Regression coefficient $\times 100$ (equivalent to $\% \mathrm{CM}$ ).

${ }^{2}$ For hypothesis, regression coefficient $=0$.

${ }^{3}$ Cow generation $=$ All cows present in the herd when the selection experiment started that were mated with one of the defined sires and produced a daughter that made a first-lactation record of mastitis and/or protein yield were defined as cow-generation 0 , all their daughters were defined as cow generation 1 and so on.
} 


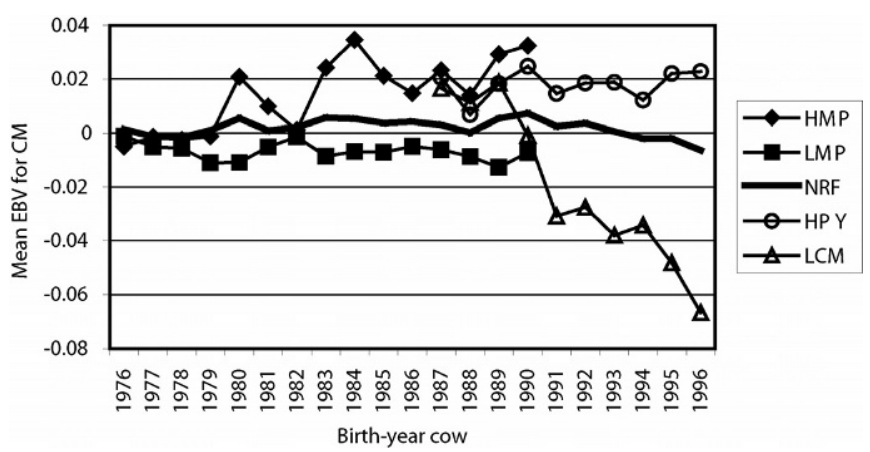

Figure 3. Mean EBV for clinical mastitis (CM) by birth-year for the Norwegian Dairy Cattle (NRF) population and for cows in two selection experiments; with high milk production (HMP) and low milk production (LMP) groups in experiment I, and high protein yield (HPY) and low clinical mastitis (LCM) groups in experiment II.

et al. (2003) from a linear sire model $(-0.23 \% \mathrm{CM})$. The genetic trend may have been somewhat over estimated with the sire model. Genetic improvement implies that the mean genetic level of the mothers of the daughters used to predict sire EBV increases over time, while the sire model assumes that sires are mated to cows at random, i.e., to cows with a constant genetic level over time. On the other hand, Heringstad et al. (2003) compared genetic change estimates from linear and a threshold sire model, and concluded that given that the threshold model holds true, the magnitude of genetic change for CM was slightly understated by the linear sire model in these data. The annual genetic response may therefore also have been underestimated with the linear animal model used in the present study.

The genetic trend of CM was larger in HMP than in HPY (Figures 2 and 3). In these experiments, sires were from the NRF population, which has changed genetically over time (Figure 3 ). The difference in genetic trends of CM between the HMP and HPY groups, both selected for increased milk production, can probably be explained by this preselection. The genetic trend for CM in the HPY group is thus not representative for what would happen in a population selected only for increased production. Rather, the difference between genetic trends for CM in the NRF population and in the HPY group describe the indirect selection response in CM resulting from selection for increased milk production.

In the time period when the genetic trend of $\mathrm{CM}$ in the NRF population was approximately flat, a genetic increase equivalent to $0.23 \% \mathrm{CM}$ per year was found for HMP cows, while in the period where the NRF population showed a genetic improvement of $-0.19 \%$ CM per year an approximately flat genetic trend
(+0.04\% CM per year) was found for HPY cows (Figure 3 and Table 7). The difference between genetic trend for $\mathrm{CM}$ in the NRF population and in the groups selected for increased milk yield, HMP and HPY, respectively, indicates that an increase between 0.19 and $0.23 \% \mathrm{CM}$ per year may be expected as a correlated response to selection for increased milk production in $\mathrm{NRF}$, given that similar selection intensities are used.

Our study is the first to quantify the correlated genetic change in CM resulting from selection on increased milk production. The results, however, agree with results from several other designed experiments reporting increased health costs as a correlated response to selection for increased milk yield (Hansen et al., 1979; Bertrand et al., 1985; Short et al., 1990; Dunklee et al., 1994; Jones et al., 1994). From a selection herd in Minnesota, Hansen et al. (1979) reported increased labor and health care expenses for cows in a group selected for high milk yield compared with cows in the control group. In the same herd Jones et al. (1994) compared health care costs for cows born from 1975 to 1990 and found that cows in the selection group had higher health expenses as a correlated response to increased milk yield than did unselected controls, and that expenses due to mastitis accounted for most of the difference between groups. Dunklee et al. (1994) evaluated a selection experiment with Holstein cows that included two groups with high and average milk yield, respectively. They reported that the high yielding cows had higher total health costs and higher mammary health costs than did the cows in the average yield group. The mean number of cases of mastitis per lactation was 0.46 in the high yield group and 0.29 in the average yield group. Bertrand et al. (1985) reported that daughters of high Predicted Difference Milk sires produced 16\% more milk, had $26 \%$ more mammary costs, and $42 \%$ more discarded milk costs, than daughters of breed average sires. Also significant differences in health costs found between a line of Jersey cows selected for milk yield and a control line were mainly due to higher mammary health costs (Short et al., 1990).

Mean EBV for 305-d protein yield per cow generation in the two selection experiments are given in Figure 4 . The difference between selection groups was significantly different $(P<0.0001)$ after cow generation 0 in both experiments. The HMP and HPY groups showed as expected a positive genetic trend for protein yield, with a genetic gain of 3.23 and $4.85 \mathrm{~kg}$ protein per cow generation (Table 7). In the LMP and LCM groups the genetic trends were negative, corresponding to a genetic change of -2.83 and $-1.97 \mathrm{~kg}$ protein per cow generation (Table 7). All these regressions of EBV for 305-d protein yield on cow generation were 


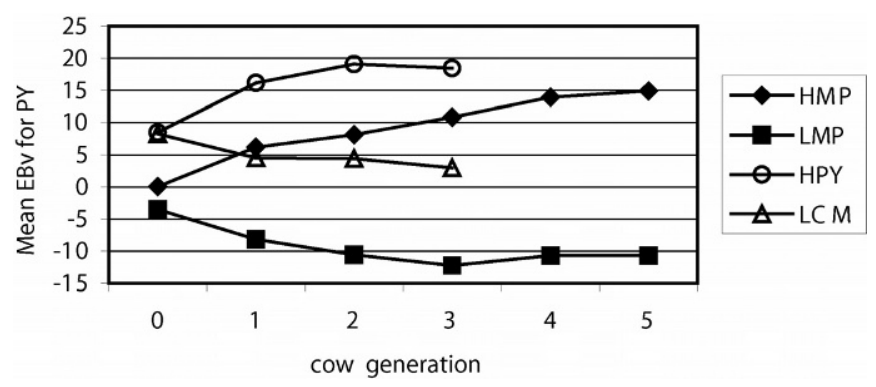

Figure 4. Mean EBV for 305-d protein yield (PY) per cow generation for cows in two selection experiments; with high milk production (HMP) and low milk production (LMP) groups in experiment I, and high protein yield (HPY) and low clinical mastitis (LCM) groups in experiment II.

significantly different from zero $(P<0.0001)$ (Table 7). In Figure 5, mean EBV for 305-d protein yield are given by birth-year for cows in the two selection experiments and also for the NRF population. The figure shows a positive genetic trend for protein yield in the NRF population, as well as for the HMP and HPY groups. The trend for the LCM group was negative, but varied as expected between years, since mean EBV for 305-d protein yield of the sires used in LCM varied strongly between years (Table 6 ). The negative genetic trend for protein yield in the LCM group is most likely a correlated response after selection against CM, due to the unfavorable genetic correlation between the two traits.

The annual genetic trend in the NRF cow population of $0.47 \mathrm{~kg}$ protein per year (Table 7 ), expected to be approximately one-half the genetic trend for AI sires, agree with Heringstad et al. (2001). They reported an annual genetic improvement of $0.96 \mathrm{~kg}$ protein per year for NRF sires born between 1974 and 1990, based on a linear regression analysis of sire EBV for 305-d protein yield on sires birth-year. The annual genetic

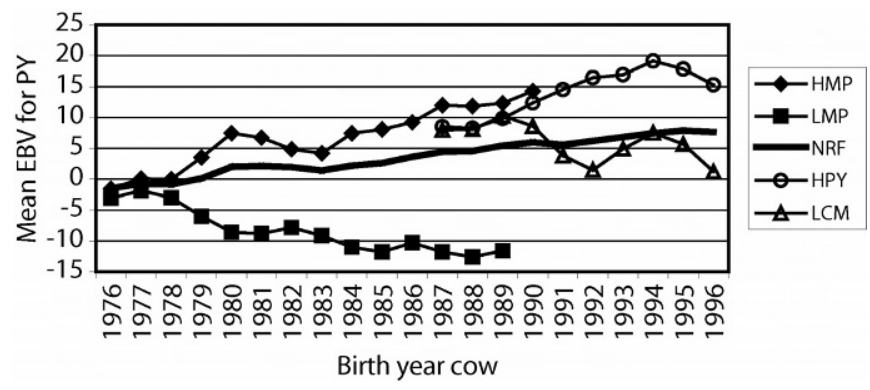

Figure 5. Mean EBV for 305-d protein yield (PY) per birth-year for the Norwegian Dairy Cattle (NRF) population and for cows in two selection experiments; with high milk production (HMP) and low milk production (LMP) groups in experiment I, and high protein yield (HPY) and low clinical mastitis (LCM) groups in experiment II. trend in the groups selected for increased milk production, HMP and HPY, was lower than the genetic trends for milk yield of US Holsteins, which according to a review by Hansen (2000) were 79, 102, and $116 \mathrm{~kg} / \mathrm{yr}$ during the 1970s, 1980s, and in the period from 1990 to 1996 , respectively (corresponding to between 2.5 and $3.7 \mathrm{~kg}$ protein per year). Selection in the HMP and HPY groups were not strict single trait selection. Although sires were selected solely based on their breeding values for milk production, they were selected among progeny-tested bulls and therefore had been preselected for NRF breeding objective with increasing weight on health and fertility over the last $20 \mathrm{yr}$.

\section{CONCLUSIONS}

The results from the two selection experiments clearly demonstrate the effect of direct and indirect selection on CM. The genetic trend for LCM cows shows that considerable selection response can be achieved for $\mathrm{CM}$ if sufficient selection pressure is put on the trait. On the other hand, if mastitis is ignored in the breeding program, selection for increased milk production will result in an unfavorable correlated selection response in $\mathrm{CM}$, as illustrated by the genetic trend for CM for HMP cows. Results for the NRF population shows that it is possible to obtain genetic improvement for both $\mathrm{CM}$ and protein yield simultaneously, if the traits are recorded for large daughter groups and given sufficient weight in selection.

\section{ACKNOWLEDGMENTS}

The herds at Åna kretsfengsel and the agricultural schools; Buskerud, Gjermundnes, Hvam, Jønsberg, Kalnes, Melsom, Mære, Valle, and Øksnevad are acknowledged for running the two selection experiments, and GENO Breeding and A. I. Association for providing pedigree information on sires. Access to the data was given by the Norwegian Dairy Herd Recording System and the Norwegian Cattle Health Service (As, Norway) in agreement number 011.2000 by October 12, 2000. This work is part of the "Healthy Cow" project financed by the Research Council of Norway.

\section{REFERENCES}

Bertrand, J. A., P. J. Berger, A. E. Freeman, and D. H. Kelly. 1985. Profitability in daughters of high versus average Holstein sires selected for milk yield of daughters. J. Dairy Sci. 68:2287-2294.

Colleau, J. J., and E. le Bihan-Duval. 1995. A simulation study of selection methods to improve mastitis resistance in dairy cows. J. Dairy Sci. 78:659-671.

Dunklee, J. S., A. E. Freeman, and D. H. Kelley. 1994. Comparison of Holsteins selected for high and average milk production. 2. 
Health and reproductive response to selection for milk. J. Dairy Sci. 77:3683-3690.

Groeneveld, E., and M. Kovac. 1990. A generalized computing procedure for setting up and solving mixed linear models. J. Dairy Sci. 73:513-531.

Hansen, L. B. 2000. Consequences of selection for milk yield from a geneticist's viewpoint. J. Dairy Sci. 83:1145-1150.

Hansen, L. B., C. W. Young, K. P. Miller, and R. W. Touchberry. 1979. Health care requirements of dairy cattle. I. Response to milk yield selection. J. Dairy Sci. 62:1922-1931.

Hansen, H., M. S. Lund, M. K. Sørensen, and L. G. Christensen. 2002. Genetic parameters of dairy character, protein yield, clinical mastitis, and other diseases in Danish Holstein cattle. J. Dairy Sci. 85:445-452.

Heringstad, B., G. Klemetsdal, and J. Ruane. 1999. Clinical mastitis in Norwegian Cattle: Frequency, variance components and genetic correlation with protein yield. J. Dairy Sci. 82:1325-1330.

Heringstad, B., G. Klemetsdal, and J. Ruane. 2000. Selection for mastitis resistance in dairy cattle-A review with focus on the situation in the Nordic countries. Livest. Prod. Sci. 64:95-106.

Heringstad, B., G. Klemetsdal, and J. Ruane. 2001. Responses to selection against clinical mastitis in the Norwegian Cattle population. Acta Agric. Scand., Sect. A, Animal Sci. 51:155-160.
Heringstad, B., R. Rekaya, D. Gianola, G. Klemetsdal, and K. A. Weigel. 2003. Genetic change for clinical mastitis in Norwegian Cattle: a threshold model analysis. J. Dairy Sci. 86:369-375.

Jones, W. P., L. B. Hansen, and H. Chester-Jones. 1994. Response of health care to selection for milk yield of dairy cattle. J. Dairy Sci. 77:3137-3152.

Lund, M. S., J. Jensen, and P. H. Petersen. 1999. Estimation of genetic and phenotypic parameters for clinical mastitis, somatic cell production deviance and protein yield in dairy cattle using Gibbs sampling. J. Dairy Sci. 82:1045-1051.

Neumaier, A., and E. Groeneveld. 1998. Restricted maximum likelihood of covariances in sparse linear models. Genet. Sel. Evol. 30:3-26.

Rupp, R., and D. Boichard. 1999. Genetic parameters for clinical mastitis, somatic cell score, production, udder type traits, and milking ease in first lactation Holsteins. J. Dairy Sci. 82: 2198-2204.

Short, T. H., B. R. Bell, D. O. Richardson, H. H. Dowlen, E. D. Moore, and J. R. Owen. 1990. Correlated responses of health costs to selection for milk yield in Jerseys. J. Dairy Sci. 73:2547-2554.

Strandberg, E., and G. E. Shook. 1989. Genetic and economic responses to breeding programs that consider mastitis. J. Dairy Sci. 72:2136-2142.

Ødegård, A. K. 2000. Avl for alle-NRF-avlen gjennom 40 år. GENO, Hamar, Norway. 